\title{
Procalcitonin is an essential biomarker for hydrocortisone, ascorbic acid, and thiamine (HAT) therapy in patients with sepsis
}

Paul E. Marik

Keywords: Vitamin C, Sepsis, Septic shock, Procalcitonin, Thiamine, Hydrocortisone

There is increasing interest in the use of hydrocortisone, ascorbic acid, and thiamine (HAT Rx) as adjunctive treatment in the management of patients with sepsis and septic shock $[1,2]$. We believe that the serial (daily) measurement of procalcitonin (PCT) is an essential component of this strategy. In our pivotal pilot study, we noted that in patients treated with HAT, PCT decreased exponentially [1]. The rate of decline of PCT over $72 \mathrm{~h}$ (calculated as the initial PCT minus PCT at $72 \mathrm{~h}$, divided by the initial PCT $\times$ 100 ) was $86 \%$ in treated patients compared to $34 \%$ in controls (see Fig. 1). The half-life of PCT is reported to be about $24 \mathrm{~h}$ [3]; this suggests that with HAT Rx, gene transcription of PCT is switched off, with the decline reflecting the elimination of PCT. Such a rapid decline in PCT has not been reported with any other therapeutic intervention for sepsis [4, 5]. This observation provides biological proof that supports our hypothesis that HAT Rx markedly attenuates the pro-inflammatory response in patients with sepsis, thereby limiting organ failure and improving patient survival [1]. Furthermore, the exponential decline in
PCT is not observed with vitamin $\mathrm{C}$ alone, when administering vitamin $\mathrm{C}$ as a continuous infusion (as a component of HAT Rx) or with alternative dosing strategies (e.g., q 12 hourly dosing of vitamin C). Remarkably, the rapid decline of PCT is even noted in patients with chronic renal failure; this finding being consistent with previous studies [3]. We have now treated over 1200 patients with HAT Rx, and the exponential decline in PCT has been a reproducible finding with few notable exceptions. We have noted that at $24 \mathrm{~h}$ after the initiation of therapy, the baseline PCT has failed to fall by $50 \%$ in two specific circumstances, namely (i) resistant organism (wrong antibiotic) or (ii) inadequate source control. This is a critical finding as it allows for the early change in antibiotics (broaden spectrum) and/or more aggressive source control. Once these issues are adequately addressed, the PCT then falls in its usual exponential trajectory. Serially monitoring PCT for at least 4 days therefore provides definitive biological proof that HAT therapy is working; failure of the typical PCT trajectory allows early recognition of ongoing inflammation (sepsis) and the need for additional interventions. 


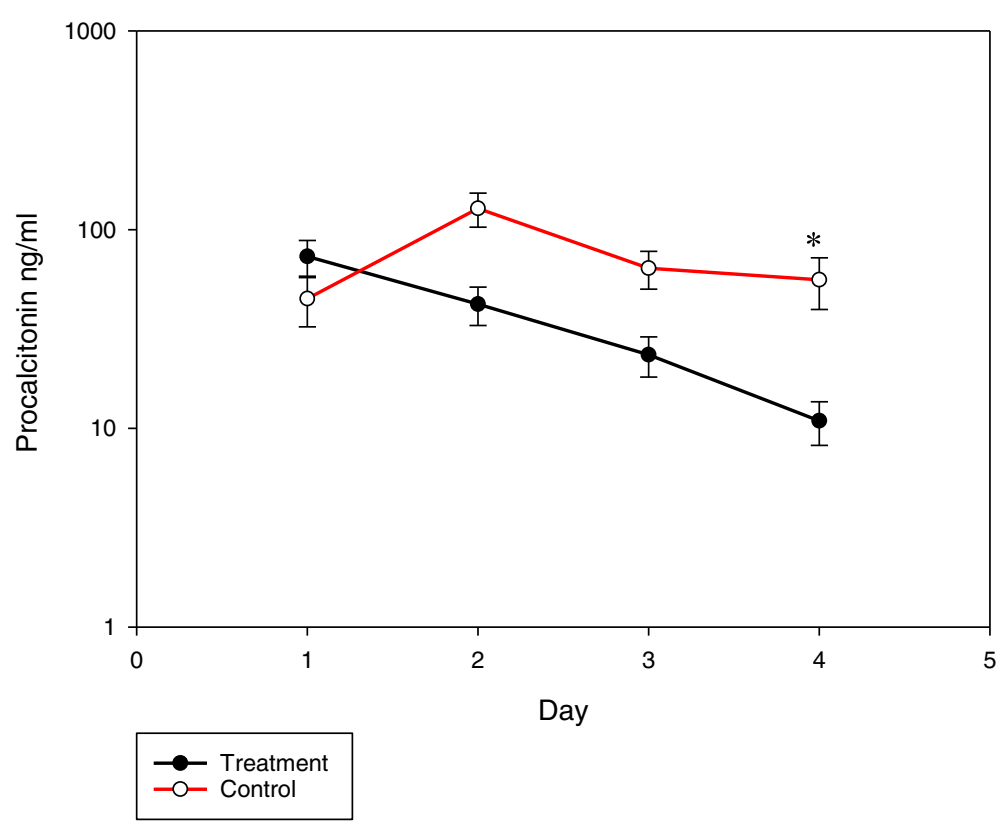

Fig. 1 Time course of the serum procalcitonin (PCT) over the 4-day treatment period in the group that received hydrocortisone, ascorbic acid, and thiamine (HAT Rx) as compared to the control group, as reported in our pivotal pilot study [1]. PCT plotted on a semilog scale. ${ }^{*} p<0.001$ for comparison of treatment group vs control group. Reproduced with permission from CHEST

\section{Acknowledgements}

None.

\section{Funding}

None.

\section{Availability of data and materials}

Available on request.

\section{Author's contributions}

The author has reviewed the final version of the manuscript and approves the manuscript for publication.

\section{Author's information}

Not applicable.

\section{Ethics approval and consent to participate}

Not applicable.

\section{Competing interests}

The author declares no competing interests.

\section{Publisher's Note}

Springer Nature remains neutral with regard to jurisdictional claims in published maps and institutional affiliations.

Received: 1 April 2019 Accepted: 15 April 2019

Published online: 02 May 2019

\section{References}

1. Marik PE, Khangoora V, Rivera R, Hooper MH, Catravas J. Hydrocortisone, vitamin $\mathrm{C}$ and thiamine for the treatment of severe sepsis and septic shock: a retrospective before-after study. Chest 2017; 151:1229-1238.

2. Moskowitz A, Andersen LW, Huang D, Berg KM, Grossesteuer A, Marik PE, Sherwin R, Hou P, Donnino MW. Ascorbic acid, corticosteroids, and thiamine in sepsis: a review of the biologic rationale and the present state of clinical evaluation. Crit Care. 2018;22:283.
3. Meisner M, Schmidt J, Huttner $H$, Tschaikowsky K. The natural elimination rate of procalcitonin in patients with normal and impaired renal function. Intensive Care Med. 2000;26(Suppl 2):S212-6.

4. Schuetz P, Bretscher C, Bernasconi L, Mueller B. Overview of procalcitonin assays and procalcitonin-guided protocols for the management of patients with infections and sepsis. Expert Rev Mol Diagn. 2017;17:593-601.

5. Schuetz P, Birkhahn R, Sherwin R, Jones AE, Singer A, Kline JA, Shapiro NI. Serial procalcitonin predicts mortality in severe sepsis patients: results from Multicenter Procalcitonin MOnitoring SEpsis (MOSES) study. Crit Care Med. 2017:45:781-9.
Ready to submit your research? Choose BMC and benefit from:

- fast, convenient online submission

- thorough peer review by experienced researchers in your field

- rapid publication on acceptance

- support for research data, including large and complex data types

- gold Open Access which fosters wider collaboration and increased citations

- maximum visibility for your research: over $100 \mathrm{M}$ website views per year

At BMC, research is always in progress.

Learn more biomedcentral.com/submissions 